\title{
Documents written by the heads of the Catechetical School in Alexandria: From Origen to Rhodon
}

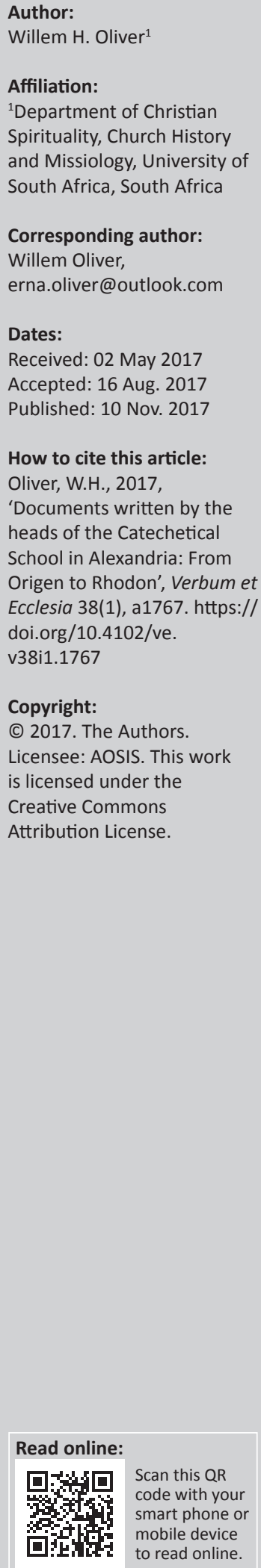

The first article of this series of two discusses and notes the documents written by the heads of the Catechetical School in Alexandria - from Mark the Evangelist to Clement of Alexandria covering the period between approximately $40 \mathrm{CE}$ and the end of the 2nd century. This article covers the period from the beginning of the 3rd century, starting with Origen and ending with Rhodon and the demise of the Catechetical School in Alexandria at the end of the 4th century. As the author could not find one single source containing all the documents written by the heads of the School, he deemed it necessary to list these documents, together with a short discussion of it where possible.

Intradisciplinary and/or interdisciplinary implications: The potential results of the proposed research are a full detailed list of all the documents being written by the heads of the School in Alexandria. The disciplines involved are (Church) History, Theology and Antiquity. These results will make it easier for future researchers to work on these writers.

\section{Introduction}

This article, being the second part of a two-article series on the heads of the Catechetical School in Alexandria, contains information on all the extant and known writings of these heads that the author could get hold of, covering the 3rd and 4th centuries. The writings of the heads of the School are noted and discussed shortly, where necessary - and only of those writers from whom we have evidence that they have written documents. The writings of the following heads are discussed: Origen, Dionysius Magnus, Theognostus, Pierius, Peter the Martyr, Serapion, Macarius Politicus, Didymus the Blind and Rhodon.

For the convenience of the reader, Table 1 is added, containing all the abbreviations of the documents being referred to inside the article.

\section{Origen}

Among the ante-Nicene writers of the Eastern Church, the greatest by far is Origen, both as a theological and as a prolific scholar of the Bible. Schaff (1885b:565) refers to him as the 'great biblical scholar and critic of the first half of the third century'. This was but half of a testimony which would be completed a century later by Tripolitis (1985; cf. also Sundkler \& Steed 2000:11) when he wrote:

Origen is an enigmatic figure, his works are difficult to analyse and understand. This difficulty is due to the fact that his writings are of a very diverse and complex nature. Some are sophisticated philosophical treatises and others are totally biblical ... Even much of his extant works in Greek are very obscure and difficult to interpret. In particular, the complex nature of his work and his pioneering speculations in his explication of the Christian views has (sic.) perplexed many interpreters of his work both in his time and through the centuries to the present time. (p. vii)

In his time, there were two distinct hierarchies in the church: the official clerical offices of the Bishop, priest and deacon, who emphasised the sacred rites of salvation, and the office of the teacher (also called instructor or lecturer), whose focus was more on the interpretation of faith

Note: This is Part 2 of a series of two articles, as a follow-up on a series of two articles that were published in 2015 in Verbum et Ecclesia on the Catechetical School in Alexandria (Oliver 2015a, 2015b). This article is based on a part of Chapters 3 of the completed DTh thesis (Oliver 2016).

This article is partially based on the author's thesis of the degree of Doctor of Theology in Church history at the University of South Africa, South Africa, with supervisor Prof. M.J.S. Madise, received March 2016, available here: http://uir.unisa.ac.za/bitstream/ handle/10500/22668/thesis_oliver_wh. 
TABLE 1: Abbreviations used when referring to documents.

\begin{tabular}{|c|c|c|c|}
\hline Abbreviation & $\begin{array}{l}\text { Full name of } \\
\text { Document/Place* }\end{array}$ & Author & Source \\
\hline Apol. contra Arian. & $\begin{array}{l}\text { Apologia contra } \\
\text { Arianos }\end{array}$ & Athanasius & Migne $1857 \mathrm{j}$ \\
\hline Bibl. Cod. & Bibliotheca Codices & Photius & Migne 1857s \\
\hline Comm. Jo. & $\begin{array}{l}\text { Commentary on } \\
\text { John }\end{array}$ & Origen & Migne 1857 e \\
\hline Comm. Matt. & $\begin{array}{l}\text { Commentary on } \\
\text { Matthew }\end{array}$ & Origen & Migne $1857 d$ \\
\hline Comm. Rom. & $\begin{array}{l}\text { Commentary on } \\
\text { Romans }\end{array}$ & Origen & Migne 1857 e \\
\hline Comment. in Esaiam & $\begin{array}{l}\text { Commentariorum in } \\
\text { Esaiam }\end{array}$ & Jerome & Migne $1857 \mathrm{~h}$ \\
\hline Cont. Cels. & Contra Celsum & Origen & Migne $1857 \mathrm{~b}$ \\
\hline De Decret. Nic. Syn. & $\begin{array}{l}\text { De Decretis Nicaenae } \\
\text { Synodi* }\end{array}$ & Athanasius & Migne 1857j \\
\hline De Princip. & De Principiis & Origen & $\begin{array}{l}\text { Augusti \& Gieseler } \\
1837\end{array}$ \\
\hline De Sent. Dion. & De Sententia Dionysii & Athanasius & Migne $1857 \mathrm{j}$ \\
\hline De Spir. Sanc. & De Spiritu Sancto & Basil & Migne $1857 \mathrm{k}$ \\
\hline De Vir. & De Viris Illustribus & Jerome & Khazarzar 2017 \\
\hline Epist. ad Amphiloch. & $\begin{array}{l}\text { Epistola ad } \\
\text { Amphilochum }\end{array}$ & Basil & Migne $1857 \mathrm{k}$ \\
\hline Epist. ad Max. & $\begin{array}{l}\text { Epistola ad } \\
\text { Maximum }\end{array}$ & Basil & Migne 1857k \\
\hline Epist. ad Pamm. & $\begin{array}{l}\text { Epistola ad } \\
\text { Pammachium } \\
\text { (Letter 48) }\end{array}$ & Jerome & $\begin{array}{l}\text { Schaff } 1885 \text { h:series } \\
2 \text {, vol. } 6\end{array}$ \\
\hline $\begin{array}{l}\text { Second Epist. ad } \\
\text { Pamm. }\end{array}$ & $\begin{array}{l}\text { Epistola ad } \\
\text { Pammachium } \\
\text { (Letter 49) }\end{array}$ & Jerome & $\begin{array}{l}\text { Schaff 1885h:series } \\
2 \text {, vol. } 6\end{array}$ \\
\hline Ex. Mart. & $\begin{array}{l}\text { Exhortation to } \\
\text { Martyrdom }\end{array}$ & Origen & Migne 1857b \\
\hline Fr. & $\begin{array}{l}\text { Fragment (Historia } \\
\text { Ecclesiastica) }\end{array}$ & Philip Sidetes & Pearse 2010 \\
\hline Haeres. & Haereses & Epiphanius & Migne $1857 q$ \\
\hline Hist. & Historia Ecclesiastica & Socrates & Migne $1857 r$ \\
\hline Hist. Eccl. & Historia Ecclesiastica & Eusebius & Migne $1857 \mathrm{~g}$ \\
\hline Hom. Lev. & Homily on Leviticus & Origen & Migne $1857 c$ \\
\hline Hom. Rom. & Homily on Romans & Origen & Migne 1857 e \\
\hline$H S$. & $\begin{array}{l}\text { A short work on the } \\
\text { Holy Spirit }\end{array}$ & $\begin{array}{l}\text { Didymus the } \\
\text { Blind }\end{array}$ & Migne $1857 m$ \\
\hline Praep. Evang. & $\begin{array}{l}\text { Praeparatio } \\
\text { Evangelica }\end{array}$ & Eusebius & Gifford 1903 \\
\hline
\end{tabular}

and the Scriptures ${ }^{1}$ taught by the church (Tripolitis 1985:6). Origen, a member of the second group, was rather critical

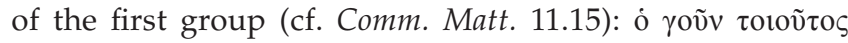

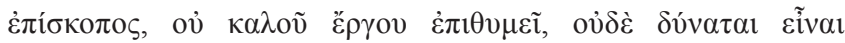

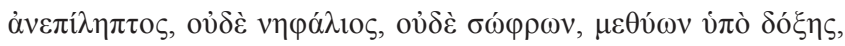

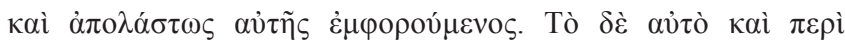

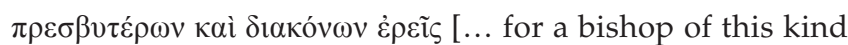
at any rate does not desire a good work, nor can he be without reproach, nor temperate, nor sober-minded, as he is intoxicated with glory and intemperately satiated with it. And the same also you will say about the elders and deacons] (Migne 1857d:936). He regarded them as men without learning, who were therefore not capable of teaching their members the Christian faith (cf. also Hom. Lev. 6.6). He spent most of his life in Alexandria as head of the School, although he visited Antioch, Athens, Arabia, Ephesus and Rome, and lived for some time in Caesarea in Palestine. Just like Clement, Origen did not engage in a hostile denunciation of the pagans, but rather engaged available to the writers, and not the whole Bible. them in highly intellectual debate in which they found it difficult to respond. Origen's writings were an attempt to present the Gospels to the pagans in such a way and style that they could make it their own (cf. Fogarty 2004:129). According to El Masri (1982:31), Origen's aim in all his writings is to clarify his two main themes: 'a loving, beneficent Creator, and free creatures'.

Clement imparted prominence to the Catechetical School in Alexandria. Origen, his student, was to take the School to its pinnacle. Schaff (1885b:546) refers to him as this other Timothy' who was taught the Scriptures as well as the literature of the Greeks by his father Leonides. According to Eusebius (Hist. Eccl. 6.2.9), Origen did not find satisfaction in the plain and obvious meaning of texts, but was always looking for a deeper significance. He was a great teacher whose aim was to explain the Scriptures to his students. It seems that he knew 'all the Scriptures' by heart: 'He had no concordance to help him; but he was himself a concordance' (Schaff 1885g:532). Added to this is the fine way in which he did textual criticism, as in his day there already existed many variations in different copies of the Scriptures. Schaff (1885g:532) calls him the first textual critic of the Church. Scrivener (1883) depicts Origen as an author in the following way:

Origen is the most celebrated biblical critic of antiquity. His is the highest name among the critics and expositors of the early Church. He is perpetually engaged in the discussion of various readings of the New Testament, and employs language, in describing the then existing state of the text, which would be deemed strong if applied even to its present condition, after the changes which sixteen more centuries must needs have produced ... Seldom have such warmth of fancy and so bold a grasp of mind been united with the lifelong, patient industry which procured for this famous man the honourable appellation of Adamantius [a nickname for Origen; cf. Oliver 2016:138]. (pp. 418, 509)

Schaff referred to him as the first great interpreter of the Scriptures in the church, even though other commentaries were written before him (Schaff 1885g:529). During the latter parts of the 2nd century, the Gnostic churches also wrote commentaries on the Scriptures. Examples are those written by Heracleon the Gnostic, allegedly of the Valentinian school (cf. Kaler \& Bussières 2006:275-289), commenting on John (often cited by Origen) and even Pantaenus, the predecessor of Clement and Origen at the School.

Origen views the sacraments as merely allegories or symbols of something spiritual to communicate the divine truth (Tripolitis 1985:7). He regards baptism as a cleansing from all

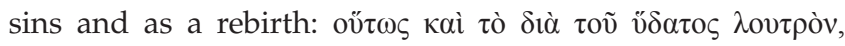

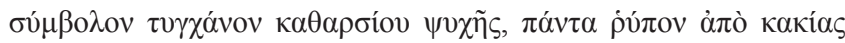

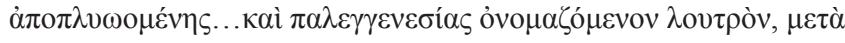

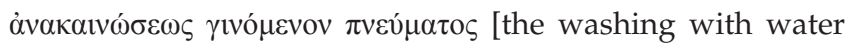
which is symbolic of the soul cleansing herself from every stain of wickedness ... and what is called the laver of regeneration takes place with renewal of the Spirit] (Comm. Jo. 6.17; Migne 1857e:252). For him the rite of unction/ confirmation formed a part of the same process (cf. Comm. 
Rom. 5.8ff.; Migne 1857e:1003ff.). The Eucharist is, according to him, one of the most important mysteries of the church - a thanksgiving/prayer to God and a source of sanctification -

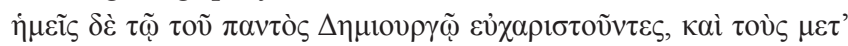

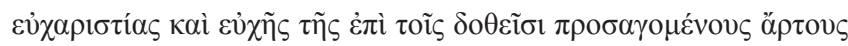

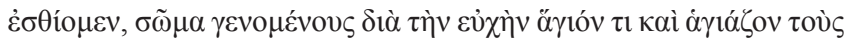

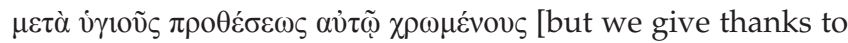
the Creator of all, and, along with thanksgiving and prayer for the blessings we have received, we also eat the bread presented to us; and this bread becomes by prayer a sacred body, which sanctifies those who sincerely partake of it] (Cont. Cels. 8.33, 57; Migne 1857b:1565), accompanied by the osculum sanctum (holy kiss) (Hom. Rom. 10.33; Migne 1857e:1283). Prayer is very important to him and he advocates

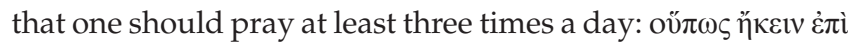

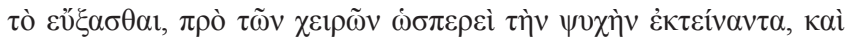

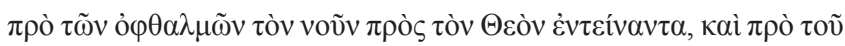

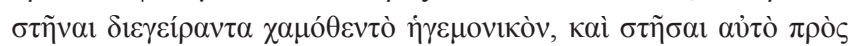
$\tau o ̀ v \tau \tilde{\omega} v$ ő $\lambda \omega v$ Kúpıv [He ought thus to enter upon prayer with his soul, as it were, extended before his hands, and his mind intent on God before his eyes, and his intellect raised from earth and set toward the Lord of all before his body stands], facing the east, either standing or kneeling with outstretched hands and uplifted eyes (On Prayer 20; Migne 1857b:549).

According to Epiphanius (Haeres. 64.63), Origen has produced a total of 6000 writings. It is assumed that he arrived at this number by including every individual treatise and each of his homilies as a separate volume or piece of writing. Unfortunately the major part (almost two-thirds) of his writings has been lost (Tripolitis 1985:11). Although many of his most important treatises have survived, in particular the

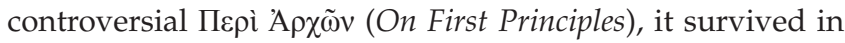
the form of 'questionable fourth-century Latin translations' (Tripolitis 1985:vii).

Origen's writings were 'heavily influential on the early Church, and for good reason, as they are inspirational and encouraging' (Schaff 1885a:1633). It is interesting to note that some of Origen's greatest rivals were fellow-Christians who thought that his views were too close to heresy (Fogarty 2004:129). The classification of his writings as done by Schaff (1885b:556-564), combined with Tripolitis (1985:11-13), is followed below.

\section{Exegetical works}

The following works are exegetical by nature:

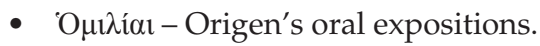

- $\Sigma \chi 0 ́ \lambda \iota \alpha$ - brief notes on the Scriptures, of which only fragments have remained.

- $\Sigma \eta \mu \varepsilon ı \omega ́ \sigma \varepsilon 1 \varsigma$ - short notes which are generally reckoned to be a third class of his exegetical works.

- Tónor (Commentaries) - written commentaries and lengthy expositions on the Scriptures, for example, on John, Matthew and Romans, written in 243 (cf. Scheck 2003:1277-1288). In these commentaries, Origen discusses the Scriptures 'without being hampered by the requirements of edification, according to the method which alone he recognizes as adequate' (Schaff 1885g:531). Because of the method he uses (cf. the explanation at the end of the preface to his De Princip. - Augusti \& Gieseler 1836:V-xvi), his Commentaries are deficient in order and sequence. Because his method has required from him to look at every verse for spiritual meaning(s), 'combined with his own extraordinary fertility of imagination and wealth of matter' (Schaff 1885g:533), the books he discusses become very disconnected. He likes to ask a number of questions and then suggests possible answers, after which he adds as many texts as he can gather from the Scriptures and then also considers them. He introduces the questions and themes very modestly, but in the end he leaves many questions unanswered, so 'that the work as a whole is rather a great collection of materials for future consideration than a finished treatise' (Schaff 1885g:533). What is very important regarding his writings is that his interests are intellectual rather than literary or practical, and scientific rather than popular.

His Commentaries on John (Migne 1857e:13-828) are the earliest available work on Christian exegesis, the 'first great work of Christian interpretation' (Schaff 1885g:529, cf. also 533). Origen has written the first five books in Alexandria between 226 and 231 (cf. Radde-Gallwitz 2011:232) and the rest in Caesarea between 231 and 238. The last one of these volumes that still exists today is volume 32 ending with John 13:33. Although it has been alleged that there were 39 volumes in total (Radde-Gallwitz 2011:232), the only volumes extant today are Volumes 1, 2, $6,10,13,19,20,28$ and 32 , of which some are not complete and some are mere fragments. These Commentaries contain several references to Heracleon who wrote the first known commentary on the Gospel of John in approximately 170 CE (cf. Comm. Jo. 2.8 where the whole chapter depicts Heracleon's view that the Logos is not the Agent of creation Migne 1857e:137-139). These references were, however, not always positive, as seen in his Commentary on John

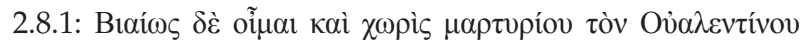

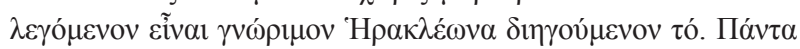

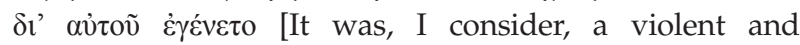
unwarranted procedure which was adopted by Heracleon, the friend, as it is said, of Valentinus, in discussing this sentence: 'All things were made through him'] (Migne 1857e:137). As a prominent Gnostic Christian and disciple of Valentinus, Heracleon was one of the most important Biblical exegetes of his day and therefore theologians like Clement and Origen had to take note of his work.

The Commentaries on the Gospel of Matthew was written at about the same time as Contra Celsum, between 246 and 248. At that stage, Origen was over 60 years of age (Schaff1885g:529, 791). These Commentaries consist of 25 books, of which the first nine are lost. Books 10 to 17 (on Mt 13:36-22:33) are extant in Greek, while the rest of the books have survived only in their Latin versions (Mt 22:34-27:66). In these Commentaries, Origen also makes use of writings that were excluded from the Christian canon, such as the Gospel of Thomas (Grosso 2011:250). 
- Homilies: Origen has written approximately 200 Homilies on the principal books of the Old Testament and New Testament. These Homilies are characterised by a 'peculiar system of interpretation' (Schaff 1885b:556), together with which he implemented his method of allegorising as much as he could. Although this method in its 'historical and literal signification offended his exegetical sense' (Schaff 1885b:556), Origen holds the

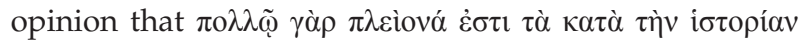

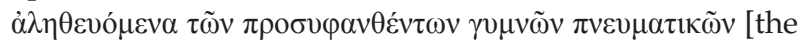
passages, however, that are true in their historical meaning are much more numerous than those which are interspersed with a purely spiritual signification] (De Princip. 4.19; Augusti \& Gieseler 1836:72). These Homilies only form a part - and not the most important part - of his exegetical works (cf. Schaff 1885g:531).

\section{Critical works}

The most important contribution Origen has made to Biblical literature is his attempt to rectify the Septuagint text by collating it with the Hebrew original and with other Greek versions (cf. Schaff 1885b:841). He began this tiring work in 214/215 (Tripolitis 1985:ix). The first form in which he published it was a Tetrapla with four columns containing the texts of the Septuagint, Aquila, Symmachus and Theodotion. After this he reworked the Tetrapla to become a Hexapla, adding the Hebrew texts accompanied by a Greek transcription of it. Ambrose (Origen's wealthy patron) employed a team consisting of writers and scribes to assist Origen by taking down the texts he dictated and by making copies of the results (Isichei 1995:21). This six-columned Bible has become Origen's great critical work. The six columns are divided as follows:

- Column 1: The current Hebrew text.

- Column 2: The text in Greek letters.

- Column 3: The version of Aquila.

- Column 4: The version of Symmachus.

- Column 5: The current text of the Septuagint.

- Column 6: The version of Theodotion.

Where appropriate, Origen has also added alternative Greek translations, increasing the six columns to seven, eight or even nine as required. El Masri (1982:30) calls this his Octapla and identifies the two other columns as two texts, called by Origen The fifth and The sixth - their authors are unknown. In these columns he inserted critical marks in the Septuagint text; for instance, an asterisk to indicate that something should be added to the text, while an obelus or cross indicates text that should be omitted. He did this textual criticism mostly at the hand of Theodotion. With this writing he actually provides a revised text of the Septuagint. He completed the Hexapla in 245 (Tripolitis 1985:xi), which means that it took him almost three decades to finish this work, during which time he travelled widely in the east to collect materials (Schaff 1885b:557). With this vast scholarly work devoted to various expositions of the different parts of the Scriptures, he displays his advanced knowledge of Hebrew, engaging in serious debate with Jewish Rabbis.
This work, consisting of some 50 volumes, was placed in a repository in Tyre. After Origen's death, it was moved to the library in Caesarea, which was founded by Pamphilus (or Pamphilius), the friend of Eusebius. When the Arabs invaded Caesarea in $653 \mathrm{CE}$, the library was burnt down. Fortunately, Pamphilus and Eusebius had copied the Septuagint text and critical marks of Origen. Subsequent transcribers, however, corrupted the text. The remains of these writings were published in two volumes in 1713 . The church of today is still indebted to Origen for the 'patient and encyclopedic labour and learning which he bestowed on the Scriptures' in his writing (Schaff 1885b:4, 546).

\section{Apologetic works}

Origen's apologetic work was aimed at pagans and Gnostics.

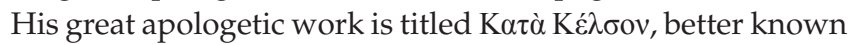
as Contra Celsum (Against Celsus), and has survived in its entirety in Greek (Migne 1857b:637-1632; cf. Arnold 2010:54; Engberg 2007:283-313). Here Origen rejects the arguments of the pagans or Gnostics because he regards them as insignificant, or based on error or wickedness. Though Spanoudakis (2010:32) argues that Contra Celsum is an 'antirrhetic' (controversial) document, this seems not to be the case: Origen particularly wrote this work in defence of Christianity against heated attacks by Celsus, who was a relatively unknown anti-Christian (Greek) philosopher who wrote a work titled $\Lambda$ ó ${ }^{\prime} \varsigma \dot{\alpha} \lambda \eta \theta \eta \dot{s}$ [True word/discourse], of which very little is known, except for the quotations from it used by Origen in his treatise. In this work, Celsus reproaches Christians as Sibyllists (cf. Cont. Cels. 5.61), meaning that they are followers of the Sibylline Oracles.

According to Schiebe (2012:472), Celsus also made another accusation, saying that 'Juden und Christen sich gewisser Teile des alttestamentlichen Narrativs schämen und deswegen bemüht seien, sie mit Hilfe der Allegorese umzudeuten' [Jews and Christians were ashamed of certain parts of the Old Testament narrative and therefore endeavoured to reinterpret it with the help of allegory; author's own translation]. In Contra Celsum 4.48, Origen refutes this accusation with a philosophical answer in which he refers to the absurdities in

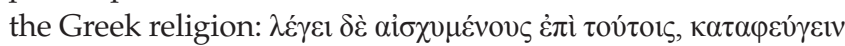

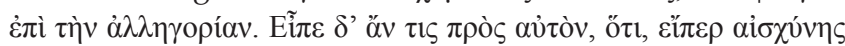

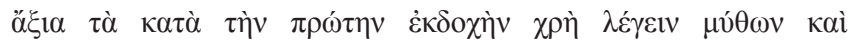

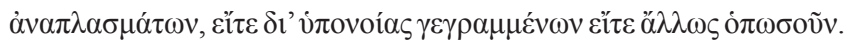

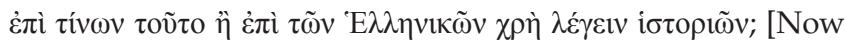
one might say to him, that if we must admit fables and fictions, whether written with a concealed meaning or with any other object, to be shameful narratives when taken in their literal acceptation, of what histories can this be said more truly than of the Grecian?] (Migne 1857b:1105). Origen views Celsus as an Epicurean who has adopted another doctrine than Epicurus in order to assail Christianity. This treatise of his, composed with great care, is 'the great apologetic work of antiquity' (Schaff 1885b:558). It consists of eight books and is written during the later years of Origen's life, but:

the rule which Origen prescribed to himself, of not allowing a single objection of his opponent to remain unanswered, leads him 
into a minuteness of detail, and into numerous repetitions, which fatigue the reader, and detract from the interest and unity of the work. He himself confesses (Contra Celsum Preface 1.6) that he began it on one plan, and carried it out on another. (Schaff 1885b:558)

In this treatise, Origen also takes a firm stand against the adversaries of the gospel who seemingly took a Jewish position against it. This compels him to establish in the first two books a perfect harmony between the two Testaments of the Bible, 'proving Christ to be the substance and sum of both' (Schaff 1885c:1384). This manuscript has survived and is held in the Vatican (Fogarty 2004:129).

\section{Dogmatic works}

The dogmatic works listed below provide an indication of Origen's views on various issues of Christian dogma:

- One of Origen's best dogmatic works is called $\Sigma \tau \rho \omega \mu \alpha \tau \varepsilon i \bar{\varsigma}$ (Miscellanies), written in 231-232. He composed this work to imitate his master, Clement. While the original writing consisted of 10 books, only three fragments remained, being translated into Latin by Jerome.

- A Treatise on the Resurrection, written in 229-230, of which only four fragments have remained.

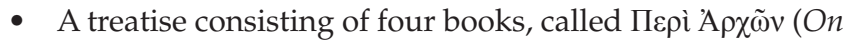
First Principles, 'amended' and translated into Latin by Rufinus of Aquileia as De Principiis, as the original Greek text has perished). When Jerome saw what Rufinus had done to the original text, he undertook a new translation, but only a few fragments of his translation have remained. This systematic presentation of the principles of Christian doctrine, written between 220 and 223 (Tripolitis 1985:ix), reveals the details of Origen's exegetical method.

It is interesting to note that this treatise of Origen has almost the same title as a document written by his predecessor, Clement. Clement's work was called On First Principles and Theology. ${ }^{2}$ The preface to this work presents the 'fundamental aim of Origen's expository writings' (Tripolitis 1985:12): According to this, the Apostles delivered only the basic doctrine of Christian faith in their writings and teachings. They did, however, not investigate or explain questions about the reasons for, or bases of their doctrines. It was for that reason that Origen thought that he had to discuss these reasons and bases. In this work, Origen teaches his readers about the noetic significance and intelligibility of creation. He adds to this the calling of humans to behold and understand the truth of what had been created (McIntosh 2012:368).

It is in this treatise, which contains Origen's views on various questions of Systematic Theology, that he has developed his system and brought his peculiar principles to the fore. In the

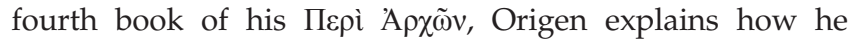
interprets the Scriptures. He argues that in the Scriptures a big part of meaning lies beyond the capacity of the ordinary mind and that this meaning cannot be retrieved by practical application. The only way to get to the real meaning is to

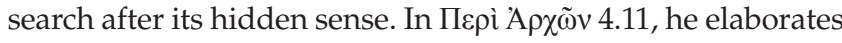

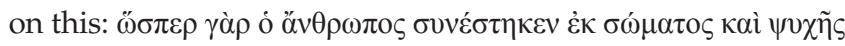

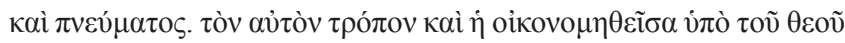

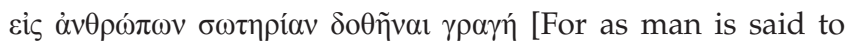
consist of body, and soul, and spirit, so also does sacred Scripture, which has been granted by the divine bounty \{i.e. God - addition added\} for the salvation of man] (Augusti \& Gieseler 1836:59). This implies that the Scriptures have three senses (meanings) - the bodily sense (the somatic sense, also called the obvious matter-of-fact sense), the psychical or moral sense (serving for edification of the pious) and the spiritual sense which is the highest of all the senses. Origen has named the last sense in no less than 40 ways (cf. Schaff 1885g:531) like the heavenly sense, the intellectual sense, the anagogical sense, the mystic sense, and the hidden sense. He argues that the highest objective of the interpreter is to discover these heavenly mysteries. With this he takes a stance against 'the notion that historical facts should be regarded as the chief outcome of a Scripture narrative' (Schaff 1885g:533). Fact has to give way for something more important: the things of the Spirit or the spiritual meaning. It is in fact this treatise that made the Church to turn against Origen (cf. Oliver 2015b:9).

\section{Practical works}

Origen wrote the following practical works:

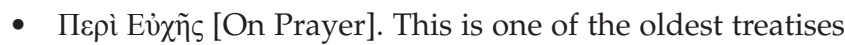
on Christian spiritual life (Gavin 2013:126) which Origen wrote at the request of his friend, Ambrose, in 233 or 236. This book contains an exposition of the Lord's Prayer.

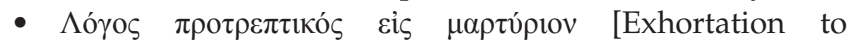
Martyrdom] (cf. Greer 1979:171-216). This work was written in 235, after Maximin ${ }^{3}$ started with his persecution and imprisoned Origen's friends, Ambrose and Protoctetus. This persecution obliged Origen to take refuge in Caesarea (in Cappadocia), where he hid for about 2 years in the house of a Christian lady called Juliana. She was the heiress of Symmachus (the Ebionite translator of the LXX) and she gave Origen several manuscripts that belonged to Symmachus. Here he composed his Exhortation to Martyrdom, which was intentionally written for the sake of his friends, Ambrose and Protoctetus, who had been freed after the death of Maximin. The death of Maximin made it possible for Origen to return to Caesarea in Palestine.

A major section of the Exhortation to Martyrdom is devoted to retelling the story of 2 Maccabees pertaining the martyrdom of Eleazar and the seven brothers, confirming the belief that their deaths were vi $\pi \dot{\varepsilon} \rho \dot{\eta} \mu \varepsilon \tau \dot{\varepsilon} \rho \omega \nu \dot{\alpha} \mu \alpha \rho \tau \eta \mu \alpha ́ \tau \omega v$

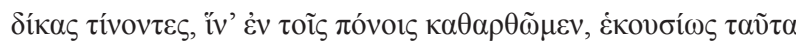
$\pi \alpha \delta \chi \omega \mu \varepsilon v$ [paying the penalty for our sins, and we are enduring these sufferings willingly, in order that by them \{the Jewish people\} may be purified] (Ex. Mart. 25; Migne 1857b:593; cf. Heisey 2004:38). In this writing, Origen calls

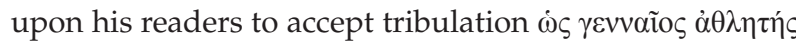
[like a noble athlete] (Ex. Mart. 1; Migne 1857b:564). He 3.This Thracian, also known as Maximinus Thrax, was the 27 th Emperor of the Roman Empire. 
recalls the martyrdom of the seven Hebrew brothers in 2 Maccabees where the older brother is depicted as an athlete

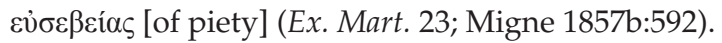

- Origen also wrote numerous letters, of which only two survived. The first letter is addressed to Julius Africanus, ${ }^{4}$ a student of Heraclas, and is called Epistola ad Africanum. It is a response to Africanus who questioned the genuineness of the history of Susanna, which forms part of the apocryphal additions to the Book of Daniel. Origen upholds the story as both useful in itself and a genuine portion of the ancient prophetical writings (Schaff 1885b:562).

The second letter that survived, called Epistola ad Gregorium, is addressed to Gregory Thaumaturgus and was written between 237 and 243 (Tripolitis 1985:x) to explain how Greek philosophy can be employed when explaining the Scriptures. In it he also mentions that the study of the Scriptures is the highest of all studies. Scientific learning can only be considered as preparatory for learning the Scriptures. The extant letter is so brief that it is possibly only a fragment of the original.

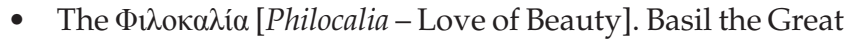
and Gregory of Nazianzus made this compilation of Origen's work to explain some difficult passages of the Scriptures (Schaff1885i:409). Large parts of this writing have been preserved, especially those from his treatise Contra Celsum. The Letter to Gregory also forms part of it as it serves as a preface to the Commentaries.

\section{Writings ascribed to Origen}

A manuscript of Hippolytus was discovered in 1842 at Mount Athos, and it was published under the name of Origen, because his name was inscribed on it. The content of the manuscript shows a marked similarity to the teachings of Origen. However, it was later established that this fragment is the long-lost Philosophumena of Hippolytus (Schaff 1885c:8). At the same time and place, another manuscript called The Refutation of all Heresies was discovered. As it was obviously a continuation of the Philosophumena and therefore another writing by Hippolytus, it was initially also ascribed to Origen (Schaff 1885c:10), as all four of the manuscripts of the first book (out of nine or 10) ascribe the writing to Origen, with words such as Refutation by Origen of all heresies, Of Origen's Philosophumena ... these are the contents, Being estimable by Origen, a man of the greatest wisdom and even Origen, and Origen's opinion. Schaff (1885c:8-14) discusses the various reasons why Origen cannot be the writer of the abovementioned writings.

\section{Final remarks on Origen}

As mentioned at the beginning of the discussion on Origen, his writings are of a diverse and complex nature (cf. Tripolitis 1985:vii). When one reads his Homilies, one discovers a 'humble and devout Christian' (Tripolitis 1985:12). However, he also has another side, which is revealed in his Commentaries (especially the two on Matthew and John) and his dogmatic

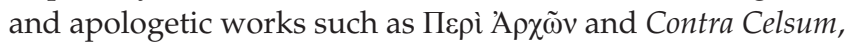
in which he is the sophisticated scholar of philosophy, especially of Plato. Moreover, Origen can only be understood completely if one treats his works as a whole, written by a man who was both a Biblical theologian and a philosopher.

\section{Dionysius Magnus}

As not many of Dionysius' writings are extant, we mainly depend on the citations of his work by Eusebius:

- De Promissionibus (A Treatise on the Promises - two books; cf. Migne 1857a:1237-1248), written in response to the book of Nepos called 'E $\lambda \varepsilon \gamma \chi 0 v \dot{\alpha} \lambda \lambda \eta \gamma o \rho ı \tau \tau \tilde{\omega} v$ (Refutation of the Allegorists; Migne 1857g:693) (cf. Hist. Eccl. 7.24: Пepi

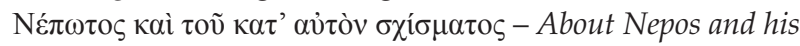
schism), referring to the Revelation of John, in which he points out that:

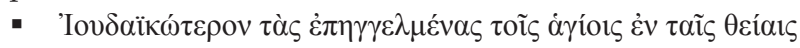

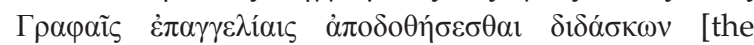
promises to the holy men in the Divine Scriptures should be understood in a more Jewish manner] (Migne 1857g:692; cf. Roberts \& Donaldson 1871:161)

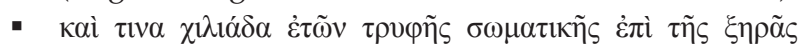

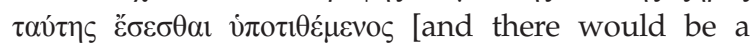
millennium period on earth, which would be replenished with corporeal delights] (Migne 1857g:692).

In Book 1, Dionysius states his own opinion concerning the above-mentioned cases; Book 2 is a discussion on the Revelation of John.

- De Natura (A Book on Nature; cf. Migne 1857a:1249-1268), addressed to Timotheus, in opposition to the Epicureans. In this book, Dionysius installs his Christian philosophy against the Epicureans, refuting their dogma that denies the existence of a providence, and refers the constitution of the universe to atomic bodies (cf. Eusebius' Praep. Evang. 14.23-27) on the grounds of:

- familiar human analogies

- the constitution of the universe

- the human constitution

- the fact that work was not a matter of pain or weariness to God.

- Fragmenta ex libris adversus Sabellium (Exercitations against Sabellius; Migne 1857a:1269-1270), addressed to Dionysius, the then Bishop of Rome (four books/letters) (cf. Praep. Evang. 7.19). In this writing, he deals with his own unguarded statements in the controversy with Sabellius (cf. Athanasius and Basil under this subheading). Regarding the two Dionysii, Schaff says that, 'with a holy jealousy they entered into fraternal explanations of the same truth, held by each, but by neither very technically elucidated' (Schaff 1885e:834).

- A Letter to Fabius detailing the persecution of Decius (New Advent 2012b).

- A Letter against Germanus referring to his own experiences of the persecution (New Advent 2012b).

- An Epistle to Bishop Basilides 'containing explanations which were given as answers to questions proposed by that bishop on various topics, and which have been 
received as canons' (Roberts \& Donaldson 1871:196). The Epistle contains four canons:

- Canon 1: On the close of the fast on the day of Pentecost.

- Canon 2: If women in the time of their separation may enter the house of God.

- Canon 3: A reference to the relations of marriage, based specifically on 1 Corinthians 7:5.

- Canon 4: Examples of Christian behaviour.

- Fragments of Epistles (forming part of the Works of Dionysius):

- Epistle 1: In his Historia Ecclesiastica 7.11.20 Chronicon,

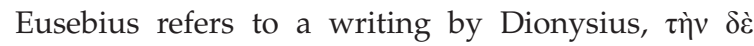

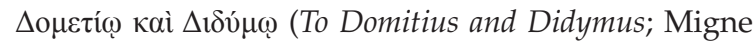
1857g:681). Roberts and Donaldson (1871:189-196) refer to it as a (second) Epistle of Dionysius to Dionysius of Rome (the first one being his Exercitations against Sabellius), also called Elenchus et Apologia, which contains a number of books. This writing concurs with a treatise written by Cyprian, named $\mathrm{On}$ (the) Mortality, depicting a pestilent disease that occurred in 'many provinces of the whole world, and especially Alexandria and Egypt' (cf. Schaff 1885c:1083; 1885d:231).

- Epistle 2: To Novatus (cf. Hist. Eccl. 6.45).

- Epistle 3: To Fabius, the Bishop of Antioch (cf. Hist. Eccl. 6.41, 42, 44).

- Epistle 4: To Cornelius, the Roman Bishop (cf. Hist. Eccl. 6.46).

- Epistle 5: His first Letter on baptism, directed to Stephen, the Bishop of Rome (cf. Hist. Eccl. 7.2, 3, 4).

- Epistle 6: A Letter to Sixtus, the Bishop. In this letter, he alludes to letters he had written to the presbyters Dionysius and Philemon, as well as to Bishop Stephen, on the baptism and the heresy of the Sabellians.

- Epistle 7: To Philemon, a presbyter of Sixtus, the Bishop of Rome, against the heresies of the time (cf. New Advent 2012b).

- Epistle 8: To Dionysius, the presbyter of Xystus. In this Epistle, he states that Novatian should be opposed because of his schism, his impious doctrine and because of the 'repetition of baptism of those who came to him' (Roberts \& Donaldson 1871:221).

- Epistle 9: A Letter to Bishop Sixtus 2 on the baptism (cf. Hist. Eccl. 7.4).

- Epistle 10: Against Bishop Germanus (cf. Hist. Eccl. 6.40; 7.11). Schaff (1885d:253) elaborates on this Epistle: Germanus before the persecutions [under Decius addition added] broke out, and of rather providing for his own safety by flight. For when persecution burst on them, the bishops were wont first to convene the people, in order to exhort them to hold fast the faith of Christ; there infants and catechumens were baptised, to provide against their departing this life without baptism, and the Eucharist was given to the faithful.

- Epistle 11: To Hermammon (cf. Hist. Eccl. 7.1, 10, 23). In this Epistle, Dionysius speaks out against Emperor Gallus.
- Epistle 12: An Epistle to the Alexandrians. Eusebius refers to this Epistle in Historia Ecclesiastica 7.22. In the preface to Historia Ecclesiastica 7.21, he says:

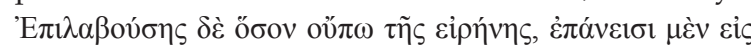

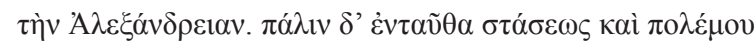

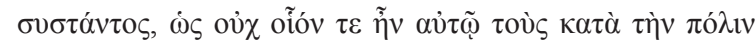

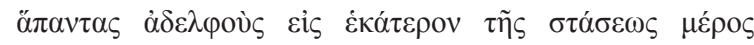
$\delta$

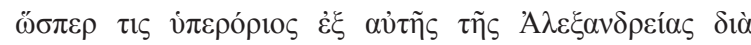

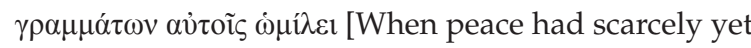
been established, he \{Dionysius\} returned to Alexandria. But when sedition and war again broke out, and made it impossible for him to have access to all the brethren in that city, divided as they then were into different parties, he addressed them again by an Epistle at the Passover, as if he were still an exile from Alexandria] (Migne 1857g:684). In Historia Ecclesiastica 7.22 , he refers to the pestilence which succeeded the Decian persecution.

- Epistle 13: An Epistle to Hierax that describes the rebellion and uproar as a consequence of the persecution (cf. Hist. Eccl. 7.21).

- Epistle 14: His Festival Epistles. In Historia Ecclesiastica 7.20, Eusebius articulates the following: In addition to these epistles, the same Dionysius also composed others about this time, designated his Festival Epistles, and in these he says much in commendation of the paschal feast. One of these he addressed to Flavius, and another to Domitius and Didymus, in which he gives the canon for eight years, and shows that the paschal feast ought not to be kept until the passing of the vernal equinox. And besides these, he wrote another epistle to his copresbyters at Alexandria.

- Exegetical fragments (cf. New Advent 2012b):

- Fragment 1: A commentary on the beginning of Ecclesiastes.

- Fragment 2: The Gospel according to Luke - An interpretation. This is done more specifically on Luke 22:42-48 in which Jesus begged his Father not to let him die on the cross.

- Fragment 3: On Luke 22:42. This fragment elaborates on the previous one, especially on the phrase 'let the cup pass'.

- Fragment 4: An exposition of Luke 22:46, connected with the preceding on Christ's prayer in Gethsemane.

- Fragment 5: On John 8:12, elaborating on the phrase 'I $\mathrm{am}^{\prime}$ and on the statement that Jesus is the reflection of the eternal light.

- Fragment 6: On the One Substance.

- Fragment 7: On the reception of the lapsed to penitence probably an excerpt from his works On Penitence.

- References to Dionysius are also found in the works of the following writers:

- Jerome (De Vir. 69; Comment. in Esaiam).

- Athanasius (De Sent. Dion.; De Decret. Nic. Syn.).

- Basil (De Spir. Sanc. 29; Epist. ad Amphiloch.; Epist. ad Max.). 


\section{Theognostus}

Theognostus, of whom we know very little, wrote seven

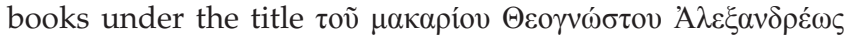

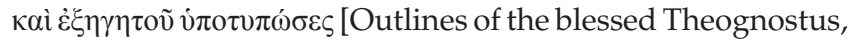
the exegete of Alexandria] (cf. Schaff1885d:374):

- Book 1: God the Father as the Creator of the universe.

- Book 2: The necessary existence of the Son.

- Book 3: The Holy Spirit.

- Book 4: Angels and demons.

- Books 5 and 6: The incarnation of God.

- Book 7: On God's creation.

Only three fragments of those seven books are extant today. Although Theognostus was a champion of the Homoousian doctrine (according to Athanasius' De Decret. Nic. Syn. 6.25ff.), Gregory of Nyssa (Book 3 Against Eunomius) accused him of, just like Eunomius, holding the wrong view on the Son's relationship to the work of creation. As there is no real extant evidence on this matter, it is almost impossible to value that accusation by Gregory.

\section{Pierius}

It seems that Pierius has devoted himself to 'sacred criticism and the study of the text of Scripture' (Schaff 1885d:378). According to Photius (Bibl. Cod. 118-119), Pierius has written a work ( $\beta 1 \beta \lambda$ íov) consisting of 12 treatises, also called sermons ( $\lambda$ óyol). In some of these treatises, he has repeated the dogmatic errors that some authors attributed to Origen, such as the subordination of the Holy Spirit to the Father and the Son, and the pre-existence of human souls (cf. Von Harnack 1897:89). Two of his works that are mentioned by Photius, which were therefore extant during his time, are the Treatise on the Prophet Hosea (also mentioned by Jerome in his De Vir. 76) and Commentary on the first Epistle of Corinthians - with emphasis on Paul's view of marriage (1 Cor 7:7; cf. also Jerome's Second Epist. ad Pamm.). The following are his known sermons (Schaff 1885d:380):

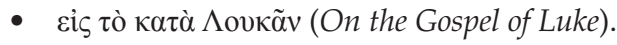

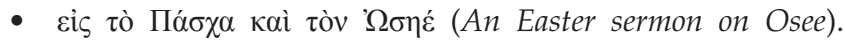
According to Radford (1908:46), this sermon was called On Easter and Hosea.

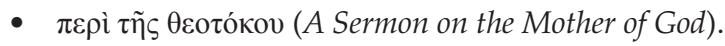

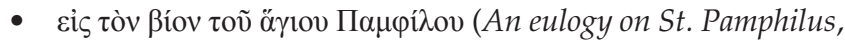
who had been one of his disciples).

- A few Easter sermons.

Except for the Sermon on the Mother of God and his Eulogy on Saint Pamphilus mentioned above, Philip Sidetes (Fr. 7 Pearse 2010) also adds the following:

- A Statement about Saint Paul's Wife from the First of the Easter Sermons.

- An etymological explanation of Biblical names, According to Pierius.

\section{Peter the Martyr}

In 306, Peter the Martyr, also known by scholars as Petrus Alexandrinus Episcopus (cf. Migne 1957e:index), wrote his
Penitential Canons (Epistola Canonica; Migne 1857f.:467-509), of which 15 were excerpted from an Easter Festal Epistle (cf. New Advent 2012c; Schaff 1885d:605) in which he addresses the people who had lapsed. Scholars and Oriental Christians of his time refer to these Canons in a collection called Responsa (Schaff 1885d:605), as well as to other fragments of his work. In a writing called Fides Patrum, the Jacobites praise Peter for his writings. Another writing called Unio Pretiosus contains a homily of Peter on the baptism of Jesus. Other extant writings by Peter are (cf. Schaff 1885d:605):

- De Deitate (Petri Sanctissimi Alexandriae Episcopi et Martyris ex Libro de Deitate - Migne 1857a:510-511): An extract of this book is included in the Acta Conciliorum Ephesini et Chalcedonensis. Three passages of this writing, apparently written in opposition to Origen's subordinationist views, were quoted by Cyril at the Council of Ephesus (New Advent 2009).

- De Adventu Salvatoris (Ex homilia De adventu Salvatoris nostri; Migne 1857a:511): A fragment of this homily is cited by Leontius Byzantinus in his first book opposing Nestorius and Eutyches, affirming the two Natures of Christ. This is also confirmed in a fragment called On the Sojourning of Christ with Us.

- Epistola ad Ecclesiam Alexandrinam (Epistle to the Alexandrine Church; Migne 1857a:510): Peter has allegedly written this Epistle after writing another one addressed to Meletius, the Bishop of Lycopolis. In this writing, he alluded to the synod held at Alexandria during which Meletius had been deposed from his office. Athanasius (Apol. contra Arian. 2.5.59) also referred to this synod when he said,

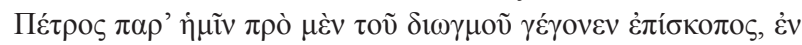

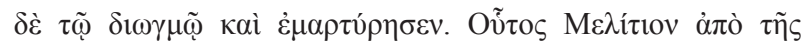

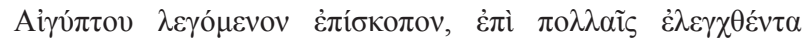

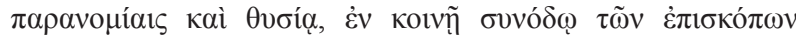
$\kappa \alpha \theta \varepsilon i \bar{\lambda} \varepsilon v$ [Peter was Bishop among us before the persecution, and during the course of it he suffered martyrdom. When Meletius, who held the title of bishop in Egypt, was convicted of many crimes, and among the rest of offering sacrifice to idols, Peter deposed him in a general council of the bishops] (Migne 1857j:356).

- Sermo in Sanctum Pascha (Migne 1857a:511-519): A passage of this sermon on the Passover was given in the Diatriba de Paschate, prefixed to the Chronicon Alexandrinum S. Paschale.

- Seven fragments are preserved in Syriac from a work on the Resurrection, in which he maintains the identity of the risen body with the earthly body against Origen.

- That up to the time of the destruction of Jerusalem, the Jews rightly appointed the fourteenth day of the first lunar month (cf. Schaff 1885d:654-657).

- De Anima et Corpore (Of the Soul and Body; Migne 1857a:519-521; cf. Schaff 1885d:658).

- Ex Doctrina Petri Alexandrini (From the teachings of Peter of Alexandria; Migne 1857a:521-522).

- In Matthaeum (On Saint Matthew; Migne 1857a:521-522; cf. Schaff 1885d:660).

- Sancti Petri Archiepiscopi et Martyris ex Sermone (Vel Libro) de Theologia (From a Sermon; Migne 1857a:521-522; cf. Schaff 1885d:661). 


\section{Serapion}

Sanctus Serapion, Thmuitanus Episcopus (Migne 1857p:index), also known as 'Serapion of Arsinoc' or 'Serapion the Scholastic', was a brilliant scholar and theologian (Catholic Online 2017). He started off as a desert monk (living in the Egyptian desert) and after the death of Antony (a hermit of the Benedictine order), he and Athanasius worked closely together, especially in their struggle against Arianism. After 343 he became the bishop of Thmuis (near Diospolis in Lower Egypt on the Nile Delta; cf. De Vir. 99). He became known through his theological writings, which consisted of the following:

- Liber Adversus Manichaeos (A book against the ideas of the Manichaeism of his time - Migne 1857:899-922) in which he contradicts their view that the soul is the work of God, while the body belongs to the devil (Rubenson 1995:103).

- Several letters that have been lost (Butler 1866:March 21).

- A treatise on the Titles of the Psalms (quoted by Jerome in De Vir. 99) that has also been lost.

- He revised writings of Athanasius directed against the Arians (Butler 1866:March 21).

- The Doctrine of the Divinity of the Holy Spirit (addressed to the Emperor) (Butler 1866:March 21).

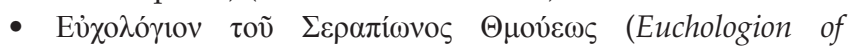
Serapion of Thmuis), translated into Latin as Euchologium - A Sacramentary (Catholic Online 2017).

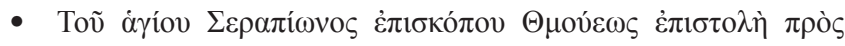

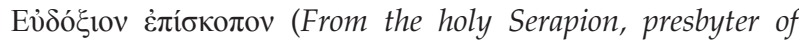
Thmuis, to the presbyter Eudoxius - Migne 1857:923-926).

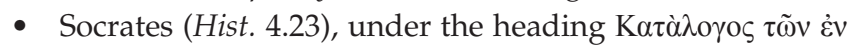

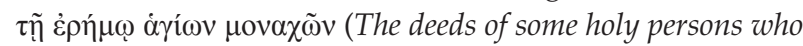
devoted themselves to a solitary life - Migne 1857r:509), refers to Serapion as an angel of the Church, referring to words uttered by the latter which are not extant anymore:

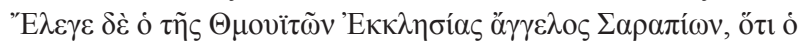

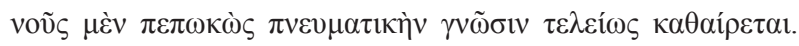

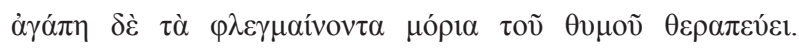

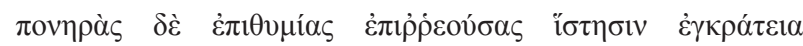
[Serapion, the angel of the church of the Thmuitae, declared that 'the mind is completely purified by drinking in spiritual knowledge': that 'charity cures the inflammatory tendencies of the soul' and that 'the depraved lusts which spring up in it are restrained by abstinence'] (Migne 1857r:520).

\section{Macarius Politicus}

The only source containing any reference to writings by Macarius that could be found was Biblical Training (s.a.), according to which ' $[a] \mathrm{n}$ extant monastic rule containing 30 regulations for his 5000 monks of the Nitrian desert and a sermon on the eschatology of souls are among the writings ascribed to him'. Migne $(1857 \mathrm{~m})$ refers to Macarius of Alexandria and notes the Sancti Macarii Alexandrini Scripta, but sorts them together with the documents written by Macarius' big friend Macarius of Egypt.

\section{Didymus the Blind}

The fact that Didymus was blind did not prevent him from writing a large number of documents, most of which are fragments or 'short works' and commentaries, of which only a few survived. He combines the theological way of thinking and vocabulary of Athanasius with the style of two much younger writers of his time in the persons of Basil and Gregory Nazianzus (Leipoldt 1905:26, 31).

Didymus seemingly supports the idea of the pre-existence of the soul (New Advent 2012a). Jerome (in De Vir. 109 he calls Didymus ó B $\lambda \dot{\varepsilon} \pi \omega v$ - the seer[!]) attributes, on the evidence of Didymus' Commentaries on 1 Timothy and 1 Peter, the doctrine of the 'restitution of all things' to him as he had taught in these commentaries that the fallen angels and even Satan himself would be saved by Christ, yet he often speaks of eternal punishment. For him God's punishments will be remedial. From his Trinitarian and Christological teachings it is clear that he was not influenced or convinced by Origen's views (cf. New Advent 2012a).

The tone of his writings is always well balanced and calculated with the intention to rather win over his opponents than to defeat them. He deals harshly with heresies, but never with the person(s) behind the heresies. A point of critique against him is that his writing style is 'poor and careless' (New Advent 2012a).

This article follows the classification of Migne (1857n:2691818), who divides the works of Didymus into two groups, called the Didymi Scripta Dogmatica [Dogmatic works of Didymus] and Scripta Exegetica [Exegetical works]:

- Scripta Dogmatica:

- De Trinitate libri tres. According to Leipoldt (1905:5), Didymus has written two documents on the Trinity: (1) De Trinitate: These three books, composed after 379 (cf. New Advent 2012a), are almost entirely preserved

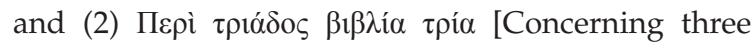
Books on the Trinity]: The first book deals with the Son, while the second book relates to the Holy Spirit. In the third book, he discusses the most important Biblical proofs of his opponents. These books were finished by 392.

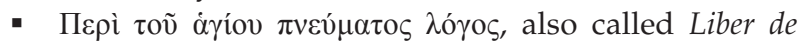
Spiritu sancto [A short work on the Holy Spirit] addressed to Paulinianus (cf. Apol. 2.24). In this writing, Didymus makes numerous (different) references to the Holy Trinity. He is credited with the

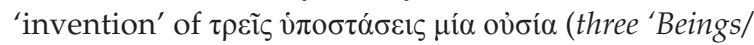
Creatures', one Being; cf. Leipoldt 1905:2). This is actually a clumsy use of words, as Didymus admits

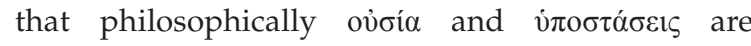
synonyms, both referring to the Latin persona (cf. New Advent 2012a). Because until the 4th century the Greek-speaking Church had no means of expressing the doctrine of the Trinity, Leipoldt 
(1905:10) suggests that Didymus did not know the

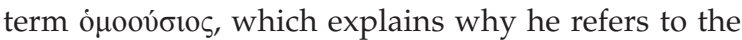
Trinity as una substantia (HS. 16.1049A), una essentia (HS. 36.1065A) and una natura (HS. 18.1050B). He also refers to the Trinity as a special substantia (HS. 1.1033C), essentia (HS. 4.1035B) and natura (HS. 23.1053A). These references are made in Latin, because the original writings of Didymus on the Holy Spirit are preserved only in the Latin translation made by Jerome (De Vir. 109).

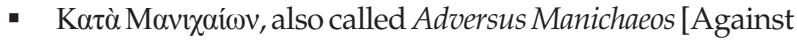
the Manichaeans]. In this treatise, which is almost completely extant, Didymus refutes the Manichaeans with philosophical proofs and a debate on controversial

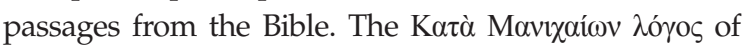
Gregory of Nyssa is almost a direct (sometimes abridged) citation of this treatise of Didymus.

- Fragmenta ex libris deperditis [Fragments from lost books].

- Scripta Exegetica: Didymus wrote quite a number of commentaries, of which only a few are extant. From his commentaries it is obvious that he was influenced by Origen, even with regard to the use of the text and grammar, as well as his wide allegorising; however, from his extant work it is clear that he was not much influenced by Origen's 'heresies':

- Fragmenta in Genesin ex Catena Graeca in Pentateuchum Lipsiae anno 1772 edita [Fragments on Genesis from the Catena Graece in Pentateuchum Lipsiae, edited in 1772].

- Fragmenta in Exodum [Fragments on Exodus].

- Fragmenta in Regum librum II [Fragments on the Second Book of Kings].

- Fragmenta in Job, ex Catena Nicetae [Fragments on Job, from the Catena Nicetae].

- Expositio in Psalmos ex codd. Vatic. et Nanian [Commentary on Psalms, from Codex Vaticanus and Nanianus].

- Fragmenta Expositionis in Proverbia [Fragmentary Commentaries on Proverbs].

- Fragmenta Expositionis in Joannem evangelistam [Fragmentary Commentaries on the Gospel of John].

- Fragmenta Expositionis in Actus apostolorum ex Wolfii Anecdotis [Fragmentary Commentaries on the Acts of the Apostles from Wolf's anecdotes].

- Fragmenta Expositionis in Epistolam II ad Corinthios [Fragmentary Commentaries on the Second Epistle to the Corinthians].

- Quaestiones ac Vindiciae Didymianae sive Didymi Alexandrini Enarratio in Epistolas catholicas Latina magnam partem e Graecis scholiis restituta, ex editione Chr. Friderici Lucke, Gottingensis [Questions and claims of the Didymianae about the Commentary of Didymus of Alexandria on the Catholic Epistles, of which a big part was in Greek, and was restored in Latin in the book of C Friedrich Lucke in Göttingen].
- Didymi Enarratio in Epistolas catholocas [Didymus' Commentary on the Catholic Epistles]: This commentary is only known through the Latin translation undertaken by Epiphanius for Cassiodorus.

Added to these, Leipoldt (1905:9-31) ascribes the following works to Didymus:

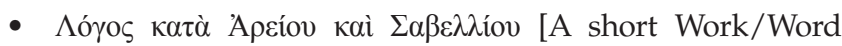
against Arius and Sabellius]. This document was published under the name of Gregory of Nyssa, but was later proved to have been written by Didymus. Together with Arius and Sabellius, another person called Achillius, who was initially involved in the Arian struggle, is also named in this work.

- De Dogmatibus (Dogmatic works, referred to by Jerome in De Vir. 109). In this writing, Didymus discusses the creative activity of the Holy Spirit.

- Contra Arianos libri duo. This could be an extension of his De Dogmatibus and was completed in 392. Jerome also refers to this work (De Vir. 109).

- Sectarian Works [Works against Sectarians]. Didymus argues in these works that the Holy Spirit does not receive wisdom, but that he is wisdom. According to Leipoldt (1905:10), this is a Lieblingsgedanke [favourite idea] of Didymus.

- After Jerome. In 386, at the request of Rufinus of Aquileia (cf. Rufinus 3.28), Didymus wrote a book on the issue of why young children die.

- After Jerome. This can be the same document as the previous, or a second document with the same name, directed against Eunomius (cf. De Vir. 120). According to Leipoldt (1905:11), it is not clear whether in these writings Didymus refers to the Trinity as one or as three entities.

- After Jerome (cf. Epist. ad Pamm. 48.19) written in 393. Whether this is a third document with the same name, a later addition to the previous documents or a document totally distinguished from the previous two, is not clear. However, what is clear is that it is written about 7 years later than the first document.

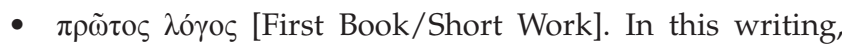
Didymus discusses the Holy Trinity and more specifically the Holy Spirit. He refers to 14 texts in the Bible and deals with each in a separate chapter - therefore the document consists of 14 chapters.

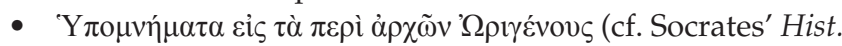

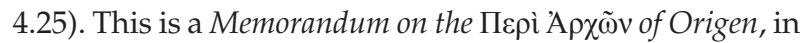
which Didymus defends Origen who, according to him, has been misunderstood by his accusers.

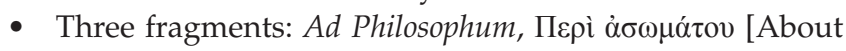

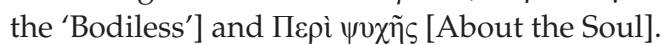

- Commentary on 2 Peter, from which Epiphanius frequently quotes (Leipoldt 1905:31).

Jerome (De Vir. 109; cf. Khazarzar 2017) names a collection of commentaries written by Didymus, which Leipoldt (1905:11) refers to as 'exegetical fragments':

- Commentarios in psalmos omnes [Commentaries on all the Psalms].

- Commentarios in Evangelium Matthaei et Joannis [Commentaries on the Gospels of Matthew and John]. 
- In Isaiam tomos decem et octo [Eighteen volumes called On Isaiah].

- In Osee, ad me scribens commentariorum libros tres [Three books of commentaries called On Hosea addressed to me \{Jerome\}].

- In Zachariam, meo rogatu, libros quinque [Five books called On Zechariah, written at my \{Jerome's\} request].

- Commentarios in Job, et infinita alia quae digerere proprii indicis est [Commentaries On Job and many other things].

- Two treatises were originally ascribed to Didymus, but it was later concluded that he was not the writer:

- Pseudoathanasius contra Apollonarium. This is a treatise written by Ambrose, a student of Didymus (Leipoldt 1905:26).

- Pseudobasilius adversus Eucomium. After a long discussion Leipoldt (1905:26-31) cannot really conclusively identify the author of this writing, although he is convinced that it is not Didymus.

\section{Rhodon}

Rhodon was referred to by Eusebius (Hist. Eccl. 5.13) as

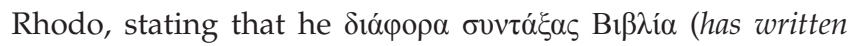
several books - Migne 1857g:460), like the one against the heresy of Marcion, and against the blasphemous Apelles (Schaff 1885f:2043). He was also initially credited with writings against heretics like the Cataphrygians, but these were later ascribed to Asterius Urbanus (Schaff 1885f:2043). Nothing more is known about the writings of this scholar.

\section{Conclusion}

Even with all the effort in collecting all the documents written by the heads of the Catechetical School in Alexandria, it is absolutely possible that there could still be more or that more could be discovered. This article, together with the previous one, acts as an invitation to the readers to do more research on the subject because there are enough extant documents to make such research possible. Further research is important, as these documents laid the foundation for the theology of that School, as well as the theology of the earliest Christians.

\section{Acknowledgements Competing interests}

The author declares that he has no financial or personal relationships that may have inappropriately influenced him in writing this article.

\section{References}

Arnold, J., 2010, 'Textkritisches zu origenes' Contra Celsum', Vigiliae Christianae 64 54-73. https://doi.org/10.1163/004260310X12584264873969

Augusti, J.C.W. \& Gieseler, J.C.L., 1836, Origines De Principiis, Digitized by Google, viewed 02 August 2017, from https://archive.org/stream/originesdeprinc00 redegoog\#page/n1/mode/2up

Biblical Training, s.a., Macarius of Alexandria, viewed 26 April 2017, from http://www. biblicaltraining.org/library/macarius-alexandria

Butler, A., 1866, The Lives of the Fathers, Martyrs, and Other Principal Saints, vol. III: March, St. Serapion, Bishop of Thmuis, in Egypt, Confessor, James Duffy, Dublin.
Catholic Online, 2017, St. Serapion the Scholastic, viewed 26 April 2017, from http:// www.catholic.org/saints/saint.php?saint_id $=2501$

El Masri, I.H., 1982, The story of the Copts: The true story of Christianity in Egypt. Book 1: From the Foundation of the Church to the Arab invasion, St. Anthony Coptic Orthodox Monastery, Newberry Springs, CA.

Engberg, J., 2007, 'Impulsore Chresto: Opposition to Christianity in the Roman Empire c. 50-250 AD', in D. Brakke, A.-C. Jacobsen \& J. Ulrich, J., (eds.), Early Christianity in the Context of Antiquity, vol. 2. Peter Lang GmbH Europäischer Verlag der Wissenschaften, Frankfurt am Main.

Fogarty, M.E., 2004, 'Egyptian Christianity: An historical examination of the belief systems prevalent in Alexandria C.100 B.C.E - 400 C.E', Unpublished MPhil thesis, Dept. of Ancient Near Eastern Studies, University of Stellenbosch.

Gavin, J., 2013, 'Becoming an exemplar for God: Three early interpretations of forgiveness in the Lord's Prayer', Logos 16(3), 126-146. https://doi.org/10.1353/ $\log .2013 .0023$

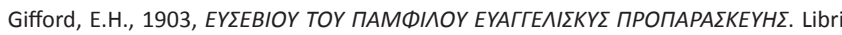
$\mathrm{XV}$. E Typographeo Academico, Oxonii.

Greer, R., 1979, Origen, SPCK, London.

Grosso, M., 2011, 'A New Link between Origen and the Gospel of Thomas: Commentary on Matthew 14,14', Vigiliae Christianae 65, 249-256. https://doi. org/10.1163/157007211X543059

Heisey, N.R., 2004, 'Martyrdom as Metaphor: Aspects of global Anabaptist witness', Conrad Grebel Review 22(3), 31-48.

Isichei, E.A., 1995, A History of Christianity in Africa, William B. Eerdmans Publishing Company, Grand Rapids, MI.

Kaler, M. \& Bussières, M.-P., 2006, 'Was Heracleon a Valentinian? A New Look at Old Sources', Harvard Theological Review 99, 275-289. https://doi.org/10.1017/ S0017816006001258

Khazarzar, R., 2017, Eusebius Hieronymus Stridonensis: De viris illustribus, viewed 02 August 2017, from http://khazarzar.skeptik.net/books/hieronym/viris_l.htm

Leipoldt, J., 1905, Didymus der Blinde von Alexandria. J.C. Hinrichs'sche Buchhandlung, Leipzig.

McIntosh, M., 2012, 'The Maker's meaning: Divine ideas and salvation', Modern Theology 28(3), 365-384. https://doi.org/10.1111/j.1468-0025.2012.01756.x

Migne, J.-P. (ed.), 1857a, Patrologiae Cursus Completus: Patrologiae Graecae Tomus X (Dionysius Magnus), Digitized by Google, viewed 02 August 2017, from https:// books.google.co.za/books?id=74S3-ku1oc4C

Migne, J.-P. (ed.), 1857b, Patrologiae Cursus Completus: Patrologiae Graecae Tomus X (Origen), Digitized by Google, viewed 02 August 2017, from https://books.google. co.za/books?id=qAkRAAAAYAAJ

Migne, J.-P. (ed.), 1857c, Patrologiae Cursus Completus: Patrologiae Graecae Tomus XII (Origen), Digitized by Google, viewed 12 August 2017, from https://books. google.co.za/books?id=SLpDsFbzv2wC

Migne, J.-P. (ed.) 1857d, Patrologiae Cursus Completus: Patrologiae Graecae Tomus XIII (Origen), Digitized by Google, viewed 02 August 2017, from https://books. google.co.za/books?id=CsZ6ejlPQAgC

Migne, J.-P. (ed.), 1857e, Patrologiae Cursus Completus: Patrologiae Graecae Tomus XIV (Origen), Digitized by Google, viewed 02 August 2017, from https://books. google.co.za/books?id=NkIFyxtsJolC

Migne, J.-P. (ed.), 1857f, Patrologiae Cursus Completus: Patrologiae Graecae Tomus XVIII (Peter Martyr), Digitized by Google, viewed 02 August 2017, from https:// books.google.co.za/books?id=D-dkJipaJfMC

Migne, J.-P. (ed.), 1857g, Patrologiae Cursus Completus: Patrologiae Graecae Tomus XX (Eusebius), Digitized by Google, viewed 02 August 2017, from https://books. google.co.za/books?id=kgwRAAAAYAJ

Migne, J.-P. (ed.), 1857h, Patrologiae Cursus Completus: Patrologiae Graecae Tomus XXIV (Jerome), Digitized by Google, viewed 12 August 2017, from https://books. google.co.za/books?id=AV4wAAAAYAA

Migne, J.-P. (ed.), 1857j, Patrologiae Cursus Completus: Patrologiae Graecae Tomus XXV (Athanasius), Digitized by Google, viewed 08 August 2017, from https:// books.google.co.za/books?id=_AORAAAAYAJ

Migne, J.-P. (ed.), 1857k, Patrologiae Cursus Completus: Patrologiae Graecae Tomus XXXII (Basil), Digitized by Google, viewed 12 August 2017, from https://books. google.co.za/books?id=phQRAAAAYAA

Migne, J.-P. (ed.), 1857m, Patrologiae Cursus Completus: Patrologiae Graecae Tomus XXXIV (Macarius), Digitized by Google, viewed 08 August 2017, from https:// books.google.co.za/books?id=GxURAAAAYAAJ

Migne, J.-P. (ed.), 1857n, Patrologiae Cursus Completus: Patrologiae Graecae Tomus XXXIX (Didymus), Digitized by Google, viewed 08 August 2017, from https:// books.google.co.za/books?id=Tlyxco1INROC

Migne, J.-P. (ed.), 1857p, Patrologiae Cursus Completus: Patrologiae Graecae Tomus XL (Serapion), Digitized by Google, viewed 08 August 2017, from https://books. google.co.za/books?id=enyn7D44nAoC

Migne, J.-P. (ed.), 1857q, Patrologiae Cursus Completus: Patrologiae Graecae Tomus XLII (Epiphanius), Digitized by Google, viewed 12 August 2017, from https:// books.google.co.za/books?id=C4P5eFG6Yg4C

Migne, J.-P. (ed.), 1857r, Patrologiae Cursus Completus: Patrologiae Graecae Tomus LXVII (Socrates), Digitized by Google, viewed 08 August 2017, from https://books. google.co.za/books?id=WivbHxoOL-sC

Migne, J.-P. (ed.), 1857s, Patrologiae Cursus Completus: Patrologiae Graecae Tomus LXVII (Photius), Digitized by Google, viewed 08 August 2017, from https://books. google.co.za/books?id=uDERAAAAYAJ 
New Advent, 2009, Council of Ephesus (A.D. 431), viewed 13 April 2017, from http:// www.newadvent.org/fathers/3810.htm

New Advent, 2012a, Didymus the blind, viewed 13 April 2017, from http://www. newadvent.org/cathen/04784a.htm

New Advent, 2012b, Dionysius of Alexandria, viewed 19 April 2017, from http://www. newadvent.org/cathen/05011a.htm

New Advent, 2012c, Peter of Alexandria, viewed 13 April 2017, from http://www. newadvent.org/cathen/11771a.htm

Norris, F.W., 2012, 'Gregory Nazianzus' Poemata Arcana: A poetic, musical catechism?', Union Seminary Quarterly Review 63(3-4), 62-75.

Oliver, W.H., 2015a, 'The Catechetical School in Alexandria', Verbum et Ecclesia 36(1) Art. \#1385, 1-12. https://doi.org/10.4102/ve.v36i1.1385

Oliver, W.H., 2015b, 'The heads of the Catechetical School in Alexandria', Verbum et Ecclesia 36(1), Art. \#1386, 1-14. https://doi.org/10.4102/ve.v36i1.1386

Oliver, W.H., 2016, 'Influence of the Catechetical School of Alexandria on the growth and development of Christianity in Africa', DTh thesis, Dept. of Christian Spirituality, Church History and Missiology, UNISA.

Pearse, R., 2010, Philip of side, fragments, viewed 07 August 2017, from http://www. tertullian.org/fathers/philip_of_side_fragments.htm

Radde-Gallwitz, A., 2011, 'The holy spirit as agent, not activity: Origen's argument with modalism and its afterlife in Didymus, Eunomius, and Gregory of Nazianzus', Vigiliae Christianae 65, 227-248. https://doi.org/10.1163/157007210X524277

Radford, LB., 1908, Three Teachers of Alexandria: Theognostus, Pierius and Peter: A study in the Early History of Origenism and Anti-Origenism, Cambridge University Press, Cambridge.

Roberts, A. \& Donaldson, J. (eds.), 1871, Ante-Nicene Christian Library: Translations of the Writings of the Fathers down to A.D. 325. Vol. 20: The Writings of Gregory Thaumaturgus, Dionysius of Alexandria, and Archalaus, T. \& T. Clark, Edinburgh.

Rubenson, S., 1995, The Letters of St. Antony: Monasticism and the making of a Saint, Fortress Press, Minneapolis, MN.

Schaff, P. (ed.), 1885a, Ante-Nicene Fathers. Vol. 3: Latin Christianity: Its Founder, Tertullian, Christian Classics Ethereal Library, Grand Rapids, MI.

Schaff, P. (ed.), 1885b, Ante-Nicene Fathers. Vol. 4: The Fathers of the Third Century Tertullian Part IV; Minucius Felix; Commodian; Origen, Christian Classics Ethereal Library, Grand Rapids, Ml.
Schaff, P. (ed.), 1885c, Ante-Nicene Fathers. Vol. 5: The Fathers of the Third Century: Hippolytus; Cyprian; Caius; Novatian; Appendix, Christian Classics Ethereal Library, Hippolytus; Cyprian;
Grand Rapids, MI.

Schaff, P. (ed.), 1885d, Ante-Nicene Fathers. Vol. 6: Gregory Thaumaturgus; Dionysius the Great; Julius Africanus; Anatolius and Minor Writers; Methodius; Arnobius, Christian Classics Ethereal Library, Grand Rapids, MI.

Schaff, P. (ed.), 1885e, Ante-Nicene Fathers. Vol. 7: The Fathers of the Third and Fourth Centuries, Christian Classics Ethereal Library, Grand Rapids, MI.

Schaff, P. (ed.), 1885f, Ante-Nicene Fathers. Vol. 8: The Twelve Patriarchs, Excerpts and Epistles, The Clementia, Apocrypha, Decretals, Memoirs of Edessa and Syriac Documents, Remains of the First Age, Christian Classics Ethereal Library, Grand Rapids, MI.

Schaff, P. (ed.), 1885g, Ante-Nicene Fathers. Vol. 9: Recently Discovered Additions to Early Christian Literature; Commentaries of Origen, Christian Classics Ethereal Library, Grand Rapids, MI.

Schaff, P. (ed.), 1885h, Nicene and Post-Nicene Fathers. Series 2. Vol. 6, Jerome: The principal Works of St. Jerome, Christian Classics Ethereal Library, Grand Rapids, princip

Schaff, P., (ed.), 1885i, Nicene and Post-Nicene Fathers. Series 2. Vol. 7, Cyril of Jerusalem, Gregory Nazianzen, Christian Classics Ethereal Library, Grand Rapids, MI.

Scheck, T.P., 2003, 'Justification by Faith Alone in Origen's Commentary on Romans and its reception during the reformation era', in L. Perrone (ed.), Origenian Octava: Origen and the Alexandrian Tradition, pp. 1277-1288, Peeters, Leuven.

Schiebe, M.W., 2012, 'Chrysippos und das obszöne Bild von Zeus und Hera. Eine forschungskritische Sichtung der Evidenz', Mnemosyne 65, 469-479. https://doi. org/10.1163/156852511X548199

Scrivener, F.H.A., 1883, A plain introduction to the Criticism of the New Testament: For the use of biblical students, 3rd edn., Deighton Bell \& Company, Cambridge.

Spanoudakis, K., 2010, 'Eusebius C. Hier. 6.5 on Man and Fowl: An instance of Christian-Pagan dialogue on a theurgic ritual', Vigiliae Christianae 64(1), 31-53. https://doi.org/10.1163/004260310X12584264873923

Sundkler, B. \& Steed, C., 2000, A History of the Church in Africa, Cambridge University Press, Cambridge.

Tripolitis, A., 1985, Origen: A critical reading, Peter Lang, New York.

Von Harnack, A., 1897, History of Dogma, vol. 3, transl. N. Buchanan, Christian Classics Ethereal Library, Grand Rapids, Ml. 